\title{
Social barriers hindering women in the performance of Akpi and Adevu musical types in Logba Traditional area in Ghana
}

\author{
Selorm Divine Ndah ${ }^{1}$, Priscilla Walden ${ }^{2}$, Okyere - Twum Ebenezer $^{3}$, Marian Sarpong ${ }^{4}$ \\ ${ }^{1}$ SDA College Of Education Creative Arts Department, Asokore - Koforidua, Ghana \\ ${ }^{2,3}$ St Monica's College of Education, Creative Arts Department, Ashanti Mampong, Ghana \\ ${ }^{4}$ Department of Ghanaian Language and Culture, Nsutaman Senior High School Nsuta - Ashanti, Ghana \\ *Corresponding Author
}

\begin{abstract}
Musical types and their performances are means by which artistes in such professions make their living. But in the Logba Traditional area in the Volta region of Ghana where the people are so much enthuse with art and cultural related events, women seems to have been left out or disadvantage when it comes to the performance of some traditional musical ensembles such as Akpi and Adevu. The study sought to find out the barriers that hinder women artistes who want to go into performance of those musical types. The study adopted the qualitative design and made use of interviews and participant observation as some of the tools for gathering data. Sampling methods that were equally used covered purposive, Snowball and Random. The target population for the study comprises music students in the area, cultural coordinators, traditional musicians, and women with musical talents. The study revealed some of the social barriers hindering women when it comes to the performance of Akpi and Adevu musical types as Taboos, superstitions and marital ties. The study is useful to society as it could serve as a reference material for musicians, anthropologies as well as policy makers in the country. The study equally recommended that, cultural festivals should be instituted in the area to help explore talents among all genders. In addition, traditional authorities should perform their rites to eliminate the superstitious and taboos barring women from engaging in the performance the traditional musical types. Besides, music in general should be giving a priority in the educational curriculum so that, it would be well appreciated in society.
\end{abstract}

Key Words: Social barriers, Taboos, Akpi, Adevu, traditional music

\section{INTRODUCTION}

$\mathrm{G}$ ender and perception could be one of the serious setbacks for women in the music industry in Ghana. For those into the traditional musical industry for example, they are measured by the standards and perceptions set by society; even though some of those societal standards might not be empirical or true. In Ghana for instance some vocations and events are associated with one gender over the other. For that matter works that require excessive use of force or energy are perceived to have being for the men, while those that have to do with lesser force is attributed to women.
In the performance of some traditional music in Ghana such as the warrior ensembles like Akpi and Adevu, the general perception is that, it is the only men who should get involved in its performance. Traditional music according to Ndah (2017) is the type that has link with traditional events such as chieftaincy, festivals and rites of passage.

Because music making is a communal and recreational activity, it is supposed to be done freely without any restrictions. Both men and women are entitle to performance of music even though in some societies, women are restricted in the performance of certain musical types due to various reasons.

The study therefore focus on the challenges that confront the women who are into the performance of those traditional dances in the research area hence recommending good solutions to addressing those challenges.

Logba, where the study was carried out is a traditional area in the Afadjato south district of the Volta Region, where performing arts are hail in the highest esteem.

\section{Statement of problem}

Many women in the Logba traditional area of the Volta Region shy away from taking part in the performance of Akpi and Adevu, even though they have the talent to do so. This assertion has been confirmed by Dovlo (2008) as well as Kquofi et al (2015). But much has not been done by scholars to dig into the causes of this phenomena hence finding lasting solutions to them. It is in this regard, that this study seeks to investigate the main social barriers hindering women in the performance of Akpi and Adevu traditional ensembles in the Logba enclave, hence finding lasting solutions to clear those barriers.

\section{Objectives}

The objectives of the study are:

1. To discuss the social barriers hindering women in the performance of Akpi and Adevu musical ensembles in the Logba area. 
2. To find solutions to the clearing of those barriers hindering women in the performance of Akpi and Adevu traditional musical types

\section{Research questions}

1. What are the barriers hindering women in the performance of Akpi and Adevu traditional music in Logba?

2. How could those barriers hindering women in the performance of Akpi and adevu traditional music in the Logba Tota be cleared?

\section{Review of related literature}

The following sub topics are review in relation to the study:

- Concept of traditional music

- Challenges facing performance of African / traditional music

- Prospects in African / traditional music

\section{Concept of Traditional Music}

Traditional music is seen among Ghanaian Communities during traditional events such as festivals.

Ndah (2017) explains traditional music as those musical types that have link with traditional themes .He substantiates that traditional music has a link with traditional events such as festivals, funerals, and the institution of chieftaincy.

In agreement with the topic under review, kquofi et al (2015) explains that traditional musical types are those that are performed by a group of people who have one philosophy and as well associate with Ghanaian institutions for that matter performed during traditional occasions such as chieftaincy affairs; thus enstoolment or enskinment in addition to life cycle events such as puberty, marriage, festivals and death.

To support the earlier scholars, Dzansi-Mcpalm (2006) describes Ghanaian Traditional music as an embodiment of issues that go on daily in our society. She further goes on that, ${ }^{\mathrm{e}}$ cultural values of indigenous Ghanaians are expressed in musical arts (music, dance, drama, and poetry and costume arts)

Amuah et al (2002) as well posit that all traditional music in Ghana are associated with dance and as well have an association with traditional Ghanaian social and political institutions such as chieftaincy. They add also that this traditional music is mostly important at the royal courts.

Observing the thoughts of all the scholars on the topic under review, one could deduce that, traditional music has a link and reflections of the immediate society and it has effects on the social, political and religious lives of the people in the environment.

Roles of Traditional Music in Ghana
The relevance of the traditional music in Ghana cannot be underestimated. In every aspects of lives of a Ghanaian, there is a musical performance.

Arthur (2009) discusses the following points as the roles that performing arts play in the Asante Culture.

a. Installation and enstoolment rights for kings, among the Asantes. She discusses that Traditional music plays a panegyric roles during the chieftaincy affairs in the Asante Kingdom. She gives example that among the Asante Culture anytime the king sits in state, the Kwadwomfoa sing to recount the exploits of their art Kings who fought for the Asante state.

b. Communication: Arthur explains that traditional music communicates among people. She explains further that among the Asante culture, when Otumfuo Osei Tutu II was nominated and accepted by the community, a song was sung. This song helps the elders to confirm acceptance of the choice. The same way if he was not to be accepted a song would have been sung to show his rejection. A stance Ndah (2017) confirms by explaining that music could communicate in two forms namely verbal and Nonverbal. He explains verbal as the messages that are sung through the music and that they directly influence members of society. The non-verbal occurs through the appellations that one plays on drums, the movements and the gestures that are displayed during the dancing. He cites an example that among the Asantes and the Ewe people that, when chiefs and other important personalities die, Atupan drums (Vuga) are played to announce the death.

c. Entertainment role: The song minstrels sing to make the King happy.

d. Music is used to inspire and encourage the commander in chief of the Asante Army during warrior situations.

Music serves as a career for those who choose it as a career. She substantiates that career exist either in the Popular, Art or Traditional musical sectors for those who have talent and therefore perform for a fee.

Ndah supports Arthur (2009) by stating that music performs panegyric roles and adds that traditional music for example is used to exalt or dignify the traditional authorities to show their powers. He cites some traditional musical ensembles as being related with traditional authorities to show their superiority. He states that among the Ewe people of Kpando, Ho and Hohoe, Akpi and Adevu musical ensembles are used to accompany chiefs when they are on a procession. Among the Asante people as well, Kete ensemble is played to accompany Otumfuo when he is in procession to a durbar. This is because the musical type depicts the supreme powers of the king. He explains that music could be used to preserve and narrate some historical events. He gives example of the migration of the Ewes from Nortsie (Republic of Togo) to the current location which is well presented in a song with text below: 


\section{English translation}

Agorkoli fe nutasese tala of king Agorkoli

Eviawo kata wodzo le egbo His subordinates run away from him

Esi wodze məla

As they run

Wozs megbe megbe movements

Wowu atikuawo

They walked with backward

Wode dzesi atiawo

They dispersed seeds

They made marks on the trees

Bena amemamlawo magabu o. So that those following could pick good signals

He cites another example of the Asante folk song that narrates the bravery of Yaa Asantewaa who led a war against the British.

Okue kue

Yaa Asantewaa

English translation In this fight

Obabesia odzina primua nue Yaa Asantewa

face the British weapon

Wa ye bi ama yen oo generation

Brave woman who could

Has done a lot for her

He substantiates that musical ensembles can help in showcasing the culture of a group of people. He gives an example of how musical events are used to showcase the culture of the people of Logba in the Volta region of Ghana during their yam festivals. He supports his point by confirming the thoughts of Aryetey (2002) that traditional drumming and dancing which is part of Ghanaian culture is used to project the cultural identity of Ghana. He discusses further that music serves as a source of livelihood to the performers.

According to Ebeli (2015) music indeed communicates. She explains that communication that music sends out manifest through the performers; through the instruments and the audience and the message that goes out. She cites Totoeme traditional ensemble among the people of Avatime and shares that, the ensemble is able to communicate and to promote peace. She explains further that the ensemble is used to project the cultural values of the people of Avatime in the Volta region.

She again discusses that the musical ensembles can be performed to accompany life cycle events citing example of Ablade (puberty rite) which is performed for female during the Easter durbar.

Ebeli continues that, Totoeme music is also performed to bid farewell to queen mothers of Avatime. She opines that the same ensemble is performed with its art during the enstoolment of Queen mothers. During the rites, the audience arrange themselves in a single file formation. A signal which communicates their readiness and their allegiance to serving and supporting the queen with all their might.

Ndah (2017) as well states further that musical ensembles play a role during the life cycle events. He outlines these events as birth, outdooring, adolescent, marriage and death. He quotes Ampomah (2000) that among the Akan in Ghana, a befitting burial to the dead is crucial and in most of the times, that is done in dirges to bid farewell. He clarifies again that music plays a role during marriage ceremonies. He supports this point by discussing the thoughts of Lodonu (2009) who explains that art forms such as music, singing and dance form part of traditional marriage among the people of Gbi in the Volta region of Ghana.

Worship whether confined to members of a cult or open to the general public involves copious use of music (Aning 2006). He discusses that among the Dagarti and Akan of Ghana, the Xylophone and Atumpan drums feature respectively in their ensemble for worshipping of their gods. Aning posits further that music functions as accompanying movement and action. Besides, music helps to hold the worshipers together.

Amu (1997) and Tetera (2006) share similar views that traditional music can be performed during funerals. Amu supports this claim by discussing that Adabatram musical type performed by the people of Ho, Peki and Wusuta in the volta region of Ghana is played during the funeral celebrations of important traditional personalities such as chiefs and Heroes.

\section{Challenges Facing African Music}

According to Onuwenski (2007), one main challenge facing indigenous African music is how to package it nicely to look attractive to the outside world. He states that, infrastructure and promotion of the musical genre are as well some of the challenges of African music as a whole.

Boyer- Dry (2008) equally adds that, financing of the African musical types as well as the influence of Westerners on the African musical types, leading to the musical type losing respect even among the indigenes, is the main challenge. He posits further that, the Western culture in the name of Christianity polluted the minds of the Africans to see any African musical type and its related arts as not being Godly. The author explains that authorities of the state even do not support the traditional cultural troupes. He cites a case of Agorsor cultural troupe in Ghana; where members lament that the state do little to support them yet whenever tourist or important personalities come to Ghana, the cultural troupe is expected to perform to entertain them.

In support of the topic under review, Dzansi- Mcpalm (2006) explains that one challenge that equally affect the African music performance is the non-inclusion of the musical type in the school curriculum from all stages of education in Ghana to create awareness among people to appreciate traditional music. 
Abdallah (2010) as well shares that the challenge of the African music in current days is the advent of technology which makes people resort to Television and other media than watching traditional musical performances. He adds that many people perceived traditional musical performers as beggars because during performances, they receive token from people.

\section{METHODOLOGY}

The study made use of qualitative design; which sought to describe events and phenomena, according to Anderson (2006). Some of the research tools adopted during the study were:

\section{*Interview \\ * Participate observation}

Interview was used to solicit data from persons who deal directly with cultural and its related fields. This instrument was very useful as it gave room for the interviewees to give out more information related to the topic under study. Interview guide was used to guide in the line of questioning.

Participant observation was as well used to gather data towards this study. This instrument helped the researchers to have firsthand information about the performances. It also gave the respondents the confidence to give out information without fear since the researchers were part of the performances. For the sampling methods used, purposive and snow ball were used to sample from the target population consisting of music students at Jim Bourton Agricultural senior high school, cultural coordinators in the Ghana Education Office and some traditional music performers in the area, not forgetting some women with musical talents. The breakdown of the population and sampling methods used is seen in a tabular form below:

Table 1: Population and sampling methods for the study

\begin{tabular}{|c|c|c|}
\hline Target population & Accessible population & $\begin{array}{c}\text { Sampling method } \\
\text { used }\end{array}$ \\
\hline Music students & 20 & Purposive \\
\hline Cultural coordinators & 05 & Purposive \\
\hline $\begin{array}{c}\text { Women with musical } \\
\text { talents }\end{array}$ & 20 & Snow ball \\
\hline $\begin{array}{c}\text { Traditional music } \\
\text { artistes }\end{array}$ & 15 & Random \\
\hline
\end{tabular}

Total number of the population for the study $=60$

\section{ANALYSIS OF DATA}

In the music students targeted group, out of 20 students who responded to the questions from the interview guide, all of them, thus $100 \%$ admitted that they love or have talent in music for that matter, traditional music. As to whether they have any problem with the performance of Akpi and Adevu traditional music, 15 of them representing $75 \%$ agreed that there are problems with these musical type regarding how the musical type is not regarded in the formal educational set- up. They as well quoted taboos and superstitions as some of the problems associated with this musical type.
As to whether they would advocate for women participation in the performance of Akpi and Adevu traditional musical type, they all agreed to YES, explaining that, those with talents could enter into that field to generate income for them just like those into production of gospel music on compact disc (CD).

All of them unanimously admitted that women shy away from this musical type because society see them as ungodly. In addition, there are certain beliefs that when women are in their menstrual cycle, they should not go close to traditional drums, else, they would be barren.

As to the way forward of Akpi and Adevu traditional music, the students suggested that traditional music should be well taught in schools to eradicate that perceptions among the people.

The responses of the 5 cultural coordinators are as follows:

They all $(100 \%)$ accepted that they love traditional music and its related arts. As to whether they have any problem with its performance, 4 out of the population, $80 \%$ admitted that there are problems when it comes to organization and performance of traditional music in their area. They cited how the state and other stakeholders neglect the musical type to its fate. They discussed further that society see those musical type as being performed by people who are not academically sound. The remaining $20 \%$ agreed that there is nothing as a problem to this musical genre as is free to be performed in society.

Asked whether they would advocate for women participation in the performance of Akpi and Adevu traditional musical type, 3 out of 5 representing $60 \%$ agreed to women participating, citing the role that traditional music plays in society; whilst the rest of the $40 \%$ stated that because of superstition, taboos and societal perceptions, they would not advocate for women to take part in the performance of those musical types.

In suggesting solutions to this challenges, they all advised that, it should be included in the formal educational system. In addition, society should be educated on superstitions and taboos in the communities. They added further that, if there are some pacifications rites to be done to appease the gods, traditional leaders should do so; so as to pave way for women to take part in the full performance of traditional drums without any fear.

The interview of the women category is as well analyze below:

They all agreed that they love traditional music for that matter enjoy its performance. They unanimously stated that they would keep on advocating for women participation only if the perception about women involvement would be changed by society.

For the challenges facing the industry, 17 out of them representing $85 \%$ discussed that the cultural practices against women such as taboos, superstition, and family ties as well as 
perception about traditional music discourage them from entering in to that field.

When asked of the solutions, they advised that, traditional authorities should make libation to the powers that be, to do away with all the taboos and the superstitious beliefs that are attached to the performance of the Traditional drums.

They explained that some of them could take up traditional musical performances as career in life when all those barriers are removed.

On the responses of the traditional musicians, they all confirmed that they have the flair for the musical type hence enjoy its performance.

They all agreed that they would advocate for participation of all sexes and as well as advocate for the perception about women in the traditional music to be changed as well.

For the challenges confronting women, they all cited superstitious issues such as barrenness, possessions by spirits, lack of husbands as some of the perceptions of the society towards those women who indulge in the performance of such traditional musical type.

\section{PRESENTATION OF FINDINGS OF THE STUDY}

Deducing and drawing conclusions from the responses of the accessible population as well as the observation made by the researchers, it could be established that women indeed have talent in the performance of Akpi and Adevu traditional musical types and its related arts just like their male counter parts as can be seen in figure 1 and 2

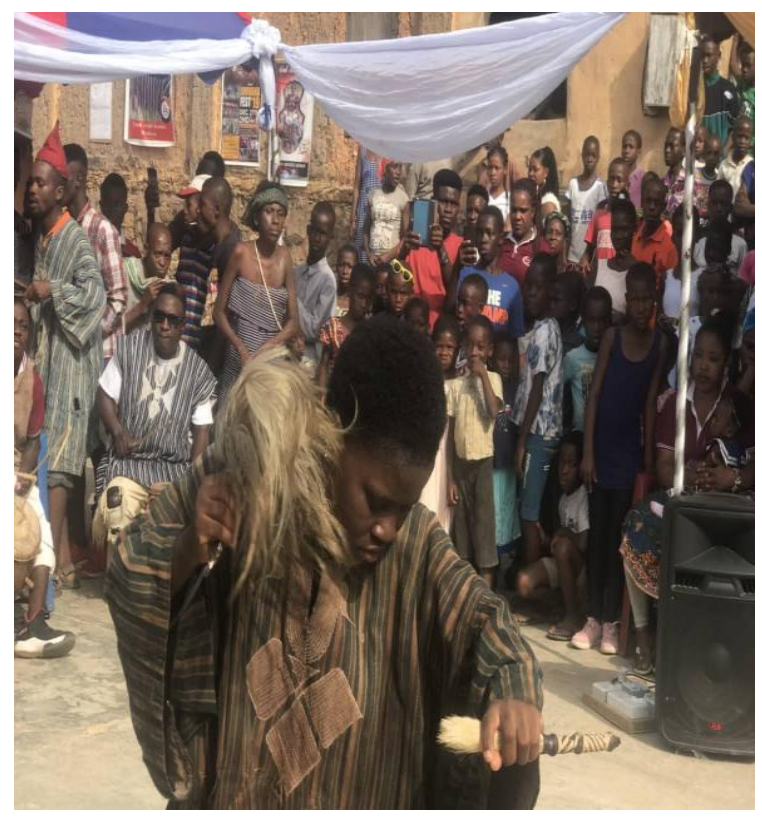

Figure 1: A school girl dancing Akpi during festival

Source: Researchers

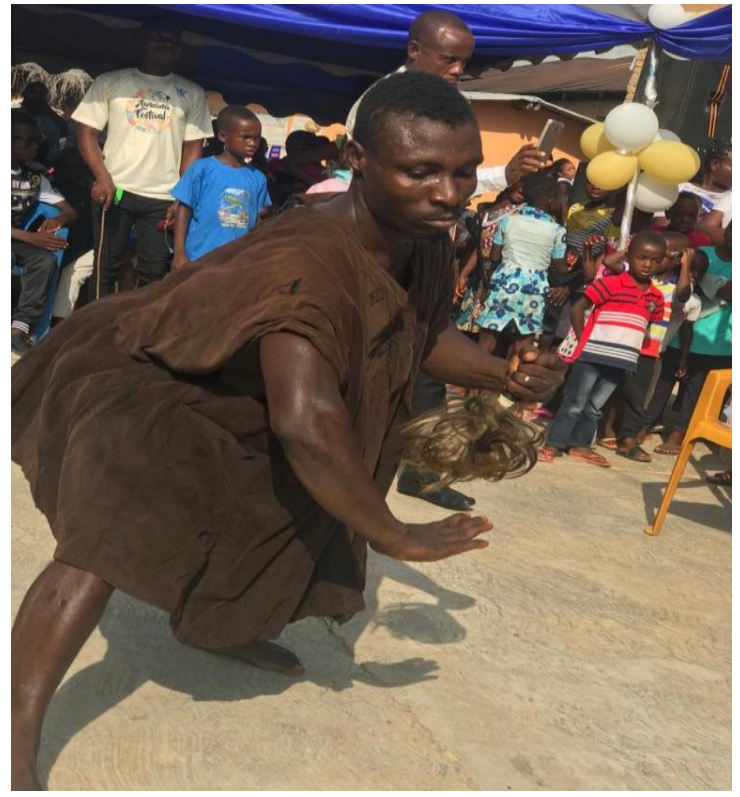

Figure 2: A man dancing Adewu during festival

Source: Researchers

The study also revealed some of the barriers hindering women during the performance of Akpi and Adevu traditional music in the research area. Some of them are discussed below:

Taboos: some of the taboos in the area forbid women to touch traditional drums; when they do, the belief is that, they would become barren. In addition, they should not go near traditional drums when they are in their menstrual cycle, as they are perceived to be unclean to defile the gods that own the drums. Should they defy those barriers, they would have to face the full rigours of the law in the traditional courts in the society.

Superstitions: it is believe that, gods in the area like music especially the traditional ones. So any woman who involves in the performance would be married spiritually by the gods. And when that happens, the women in question would find it difficult to get a husband physically. And since marriage is a requirement for women in the study area, they are compel to drop their musical talents all in the name of superstition.

Marital ties: society frowns on women who partake in such ensembles. They are viewed as irresponsible who could not keep their homes; but use the time to performed traditional music. Once a woman is married, traditionally, attention is focused on her to have time with the husband with the house chores and keeping the home. Society therefore sees that as a top most priority other than engaging in things like performance of traditional music even if she has an interest or talent to do so. For fear of what society would tag them with, they give up on their musical ambitions so as to meet the demands of the society.

Lack of motivation from the state and authorities: the study shown that this musical type is not giving recognition in society by the state. So women are not motivated to go into its performance as professionals, even though many of them have 
the talent and flair for its performance. This point seems to confirm the assertion of Boyer- Dry (2008). The industry players in the country are all geared towards the performance of popular musical types with modern technology, a situation that is not motivating enough for the music makers especially the women to enter into the performance and production of the traditional musical types.

Religious doctrines: Christianity and religious inclinations as well serve as hindrance in the involvement of traditional music for all including women. All the Christian based religions in the area, see performance of Akpi and Adevu together with their participants as non-Christian and whenever any of their members is seen taking part in its performance, he or she is ex communicated from the church because they regard the activities of the whole ensemble as ungodly.

Some of the solutions to overcome the barriers are equally discuss below:

The traditional authorities should intervene, make rituals or animal sacrifices to pacify the gods to allow for the women who have such artistic talents to feel free to exhibit them to benefit society and themselves.

In addition, mass education should be carried out by the media in the area for people to see or appreciate performance of traditional musical types as career, profession and for that matter, source of income for those who want to engage into its performance.

Policy maker as well as the curriculum planners should give special attention to the study of music in general and traditional music in particular. Music should be made a core subject from the basic levels to the tertiary levels of the educational ladder in the country; and should be examinable at all levels. With that, all the negative perceptions about the study and performance of traditional music and other musical types would be erased.

Music and Cultural festivals should be instituted in the area where cultural assets such as musical types could be display to showcase the culture of the people; a situation which would make them appreciate their own cultural heritage better.

The artistes in the area could start composing their music blending the sacred and the traditional elements together. For example using sacred words into the rhythm of Akpi or Adevu musical type. A situation which would proof to all that, performance of those musical types alone is not anything that is bad.

\section{CONCLUSION}

Many women are talented in the field of traditional music but are been restricted by societal norms such as taboos, that forbid women from performance of traditional music else, they would be barren. In addition, they should not go close to traditional drums when they are in their menstrual cycle. Furthermore, society insults women as irresponsible people who could not cook for their husbands; yet they indulge in the performance of traditional music. See a picture of Akpi musical ensemble on Figure 3 consisting of all male participants, because of the societal restrictions.

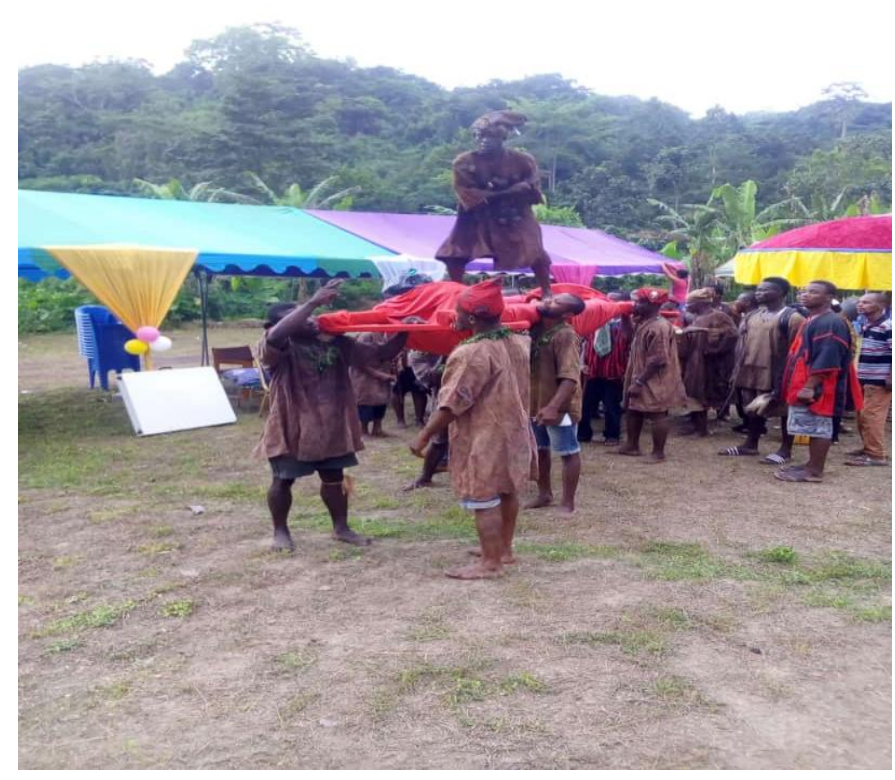

Figure 3: Asafohene dancing to the tune of Akpi during traditional festival (at the background, all participants are male)

Photograph: The researchers

The study however made it clear that, there are many prospects in music as a whole and traditional music in particular. So policy makers should give teaching of music the needed attention in schools so as to eradicate any negative perception about its performance in society. In addition, traditional authorities should work to remove the superstitious barriers hindering women into the performance of Akpi and Adevu musical types in the Logba area.

\section{RECOMMENDATIONS}

1. Traditional authorities should institute traditional based cultural festivals to showcase the talents of women who have the flair for the performance of traditional music and other musical type in the area.

2. Cultural centres should liaise with chiefs and traditional leaders in the area to recruit those women who are good in the traditional dances as performers and instructors at their centres.

3. Ghana Education Service, should liaise with the communities to use those women as resource person during cultural festivals that currently take place in the first and second cycle schools.

4. Traditional authorities should pacify their gods so as to remove some of the outmoded taboos and beliefs which can allow women to pursue their chosen careers in traditional music.

5. Music should be giving special attention in the school curriculum so that it would be fully appreciated in society. 


\section{REFERENCES}

[1] Abdallah, Z.Z (2010) The lunsi institution of Dagbon: sustainability in the balance. Journal of performing arts 4 nos (2). 157 - 172. Retrieved from http// ugspace.ug.edu.gh

[2] Arthur, N.P (2009) The role of performing arts in the Asante Culture. Thesis submitted to the School of Graduate Studies, Kwame Nkrumah University of Science and Technology, Kumasi

[3] Amuah, I.R, Adum- Atta, K, Arthur, K (2002) Music and Dance for Colleges of Education: Revised edition, principle and practice. Ghana: KRAMAD Publishers

[4] Aryetey, I (2002) Mastering social studies for senior secondary schools. Accra: Excellent Publishing and printing

[5] Ampomah, K (2000) The changing role of traditional Ghanaian music: implications for primary music education in Ghana. The African music educator (10). Retrieved from http: // www. scientific Africa.org

[6] Amu, M (1997) Glossary of Ewe musical terms. Retrieved from http: //archive.lib.msu.edu

[7] Aning. B.A (1975) Nnwonkro. Tema: Ghana Publishing Corporation

[8] Boyer - Dry (2008), Transforming traditional music in the midst of contemporary change: The survival of cultural troupes in Accra, Ghana. Thesis submitted to the Wesleyan University. Retrieved from http//wesscholar.weslayan.edu.

[9] Dzansi-Mcpalm, M (2006). Artistic-Aesthetic input of song leaders in African ensemble: A case of Zigi in Ghana.
International journey of community music. Retrieved from http:www.intellectbooks.co.uk

[10] Dovlo, K. (2008). A grammar of Logba (IKPANA). Lot Jankerhof 133512 BL Utrecht, the Netherlands. Retrieved from http://www.lotschool.nl

[11] Ebeli, E.A (2015) Communication processes in Totoeme music of the Avatime people of

[12] Ghana. International journal of African society cultures and traditions Nos 5(3). 134- 143 Retrieved from www.eajournals.org

[13] Kquofi, S, Ndah, S, Tabi-Adjei (2015) Serendipitous sociocultural dynamics of Logba Traditional Musical Ensembles in Ghana. European Journal of Research and Reflection in Arts and humanities No 1(3). 13 - 25

[14] Teffera, T (2006) the role of traditional music among East African Societies: The case of selected aerophones from http://www. Iiti.it

[15] Lodonu, J (2009) the artistic aspect of indigenous marriage among the Gbi of Ghana. Unpublished Mphil Thesis presented to the school of Graduate Studies, KNUST

[16] Ndah,S.D (2017) Music for Senior High Schools. Kumasi: PRISEB Publishers

[17] Onovwerosuoke, W.H.K (2007) African Art music for flute: a study of selected works by African composers. Thesis submitted to the graduate faculty of the Louisiana state University and Agricultural and mechanical college. Retrieved from http:// www.etd.isu.edu 